\title{
Hospital Saturday, Workplace Collections and Issues in late Nineteenth-Century Hospital Funding
}

\author{
STEVEN CHERRY*
}

The themes of continuity and change remain essential to an understanding of the durability of the voluntary hospital system from the eighteenth century to the establishment of the National Health Service. The voluntary hospitals provided much of the physical fabric and organized medical effort for the intended national hospital system and remained reliant upon grand philanthropic gestures, particularly for capital projects. ${ }^{1}$ Like the old hammer with a new head and a different shaft, the familiarity of the system on the eve of the Second World War was deceptive. Eighteenth-century principles of free treatment by honorary medical staff for the sick poor under subscriber-recommendation systems had very largely been replaced by the expectation of some form of payment for treating a wider social clientele of patients, including private cases, and local authority contract work, for which the honorary medical staff were paid.

The business of hospital finances has attracted the attention of historians less persuaded by the "romance" of the voluntary system or by Whiggish interpretations of its development. ${ }^{2}$ Steve Sturdy and Roger Cooter date the introduction of new business methods into some hospitals from the 1850s and the health section of the Social Science Association was investigating the criteria for hospital design and efficiency by $1860 .{ }^{3}$ As the ideology of self-help became pervasive, fears that charitable hospital facilities were being overloaded and abused were increasingly expressed, adding to the atmosphere of crisis in the voluntary hospital movement, particularly in London, by the 1870s. Bodies such as the Charity Organisation Society presented

* Steven Cherry, PhD, Wellcome Unit for the History of Medicine, School of History, University of East Anglia, Norwich NR4 7TJ.

I thank the UEA Study Leave Committee and The Wellcome Trust for their support for this research work.

\footnotetext{
${ }^{1}$ Frank Prochaska, Philanthropy and the hospitals of London, Oxford, Clarendon Press, 1992.

${ }^{2}$ A Evans and L G Redmond Howard, The romance of the British voluntary hospital
}

movement, London, Hutchinson, 1930; Steven Cherry, Medical services and the hospitals in Britain 1860-1939, Studies in Economic and Social History, Cambridge University Press, 1996, pp. 44-8, 60-3, and Keir Waddington and Anne Hardy (eds), Financing British medicine (forthcoming)

${ }^{3}$ Steve Sturdy and Roger Cooter, 'Science, scientific management and the transformation of medicine in Britain c.1870-1950', History of Science, 1998, 36: 421-66, p. 425; Michael Millman, The influence of the Social Science Association on hospital planning in Victorian England', Med. Hist., 1974, 18: 122-37. 


\section{Steven Cherry}

provident dispensaries as an alternative to voluntary hospitals, preferable on economic and ideological grounds. ${ }^{4}$ They wielded considerable influence and attracted support from sections of the medical profession opposed to medical charity. The revelation of financial irregularities and deficits in some London hospitals and concern with regard to the unevenness of hospital provision in the capital raised the possibility of state regulation of, and involvement in, the voluntary hospitals. ${ }^{5}$ Moreover, the uprating of former Poor Law infirmaries and the emergence of local authority isolation hospitals from the 1860 s suggested potential competition from the municipal sector, that "spender of other people's money", if not of wholesale municipalization. ${ }^{6}$ These were among the features attendant upon the founding of the voluntarist British Hospitals Association in 1884. Fund-raising was urgent and essential, given the dictates of the balance sheet, but the attraction of new sources of income raised other questions and, not least, changed attitudes on the part of givers and receivers. A place remained for what Geoffrey Finlayson saw as altruistic "other regarding" philanthropy, but hospital authorities who employed the methods of "grasping gratitude" sometimes had to acknowledge "bastard benevolence" and accept a degree of accountability in their arrangements. ${ }^{7}$

This article draws upon the literature of hospital finances: the pamphlets and periodicals used by administrators and reformers, the investigative and summary compilations and some hospitals' own annual reports. It briefly considers the financial situation in the hospitals before turning to the contribution of new income sources by 1900 . Workplace collecting schemes and the Hospital Saturday movement are then examined in depth, noting case examples and variance in provision. Stephen Yeo took the example of hospital collections to show, with little consequence, how "working class strata were added to old forms of social action and organisation". Contemporary hospital administrators often assumed this was also the case. My examination suggests the need to consider non-deferential motives, ranging from conscious self-help through to the assertion of rights and demands for concessions or reform, for these carried considerable implications.

\section{Philanthropy and the Hospitals}

In their efforts to secure funds, the managers and advocates of voluntary hospitals not only deepened the philanthropic market but also did much to establish their institutions as its domestic embodiment. In London it was reckoned that, excluding

\footnotetext{
${ }^{4}$ Geoffrey Rivett, The development of the London hospital system 1823-1982, London, King Edward's Hospital Fund for London, 1986, pp. $112-24$

${ }^{5}$ Thus Henry Burdett, a staunch defender of voluntary hospitals against outside interference from the State or the C.O.S., became a major exponent of hospital administrative reform. Frederic Mouat, an expert on hospital design at the Local Government Board, came to favour a state subsidized hospital service.

${ }^{6}$ Cherry, op. cit., note 2 above, pp. $48-51$.
}

\author{
${ }^{7}$ Geoffrey Finlayson, Citizen, state and social \\ welfare in Britain, 1830-1990, Oxford, Clarendon \\ Press, 1994, p. 7; Keir Waddington, 'Bastard \\ benevolence: centralisation, voluntarism and the \\ Sunday fund, 1873-1898', London J., 1994, 19: \\ 151-67, and "“Grasping Gratitude": Charity and \\ Hospital Finance in Late-Victorian London' \\ (forthcoming). \\ ${ }^{8}$ Stephen Yeo, Religion and voluntary \\ organisations in crisis, London, Croom Helm, \\ 1976, p. 217.
}




\section{Hospital Saturday, Workplace Collections}

missionary and Bible societies, medical charities received roughly 40 per cent of charitable contributions and 55 per cent of bequests over the 1880 s and $1890 \mathrm{~s} .{ }^{9}$ The number of hospital beds doubled between 1861 and 1891, exceeding population growth rates, but this expansion was most marked in provincial general, rather than metropolitan or teaching, hospitals. ${ }^{10}$ It also exceeded the growth of the special hospitals, which are often seen as the voluntary hospital sector's major development in these years. ${ }^{11}$

John Pickstone's pioneering regional study identified a range of features including medical professional influence, religious non-conformity, individualism and self-help, and industrial paternalism, within local elites, the balance of which was often critical to hospital formation and development. ${ }^{12}$ If doctors served as the instigators of such expansion, the attitude of large employers often shaped it. Around the idea of casualty facilities, geared to industrial accidents and restoring labourers to work which would enhance productivity and save the ratepayers expense, many a provincial dispensary-so often seen as a cheaper, self-help option-was transformed into a general hospital. Hilary Marland's study of Huddersfield suggests this rationale was at work before $1850 .^{13}$ It also featured in provincial towns, such as the East Anglian ports, not noted for their industrial prowess but with their share of accidents. ${ }^{14}$ Similar approaches informed the later establishment of cottage hospitals, many of which served industrial or mining communities or dealt with increasing numbers of rural accidents. ${ }^{15}$

For Pickstone the novelty in hospital expansion in north-west England lay in the re-working of employer paternalism, now supported by expressions of selfhelp within working-class communities. Thus the late-nineteenth-century hospital became not only a symbol of voluntarism but a social institution with a unifying influence. "The striking feature of the new Infirmaries was the prominence of large major capitalists and of workpeople's contributions". ${ }^{16}$ But was there a distinct or positive role for workers in these developments and were they limited only to one region? Recent outlines of the changing finances of voluntary hospitals in the early twentieth century suggest that their new income sources merit further study. This particularly applies to the various forms of collecting and contributory schemes, which originated in workplaces, in the Hospital Sunday and Hospital

\footnotetext{
${ }^{9}$ Excluding charities for the deaf, blind, disabled, etc. David Owen, English philanthropy 1660-1960, Cambridge, MA, Belknap Press of Harvard University Press, 1964, p. 479.

${ }^{10}$ Robert Pinker, English hospital statistics, 1861-1938, London, Heinemann, 1966, Tables I, p. $49 ;$ X, p. 69 ; and XIV, p. 81 .

${ }^{11}$ Lindsay Granshaw, 'Fame and fortune by means of bricks and mortar: the medical profession and specialist hospitals in Britain', in Lindsay Granshaw and Roy Porter (eds), The hospital in history, London, Routledge, 1989, pp. 199-220.

${ }_{12}$ John Pickstone, Medicine and industrial society, Manchester University Press, 1985, pp. 138-41.
} 


\section{Steven Cherry}

Saturday movements. The extent of these schemes and their importance in meeting the interwar hospitals' increased maintenance costs have been understated. ${ }^{17}$ Moreover, the representatives of such schemes often expected, and sometimes attained, a role in hospital policy beyond simple fund-raising. ${ }^{18}$ These features were most prominent in English industrial centres and Scottish cities, particularly where there was an organized labour movement. They were less noticeable in London and the rural extremities. ${ }^{19}$

Might similar remarks apply, albeit on a more limited scale, to voluntary hospitals in the late nineteenth century? It is now recognized that, quite separate from Fabian and social democratic proposals concerning the use of the state as an instrument of social policy and the establishment of a public hospital system, there was a much older grassroots interest in healthcare. In addition to herbalism, lay healing and "alternative" medicines this included the extensive use of qualified medical practitioners in organized services, confirmed in James Riley's recent work on friendly societies. ${ }^{20}$ In 18894.4 million people were assured of sickness benefits through friendly societies, and the number receiving medical attention, but not cash payments, was likely to have been much larger. ${ }^{21}$ Perhaps 9 million people were entitled to the basics of "club" medicine prior to the introduction of national health insurance in 1913. ${ }^{22}$ The Lancet estimated that between one-half and two-thirds of urban populations obtained medical attention through sick clubs, with half of all doctors involved in contract practice. ${ }^{23}$ In Scotland, 280,000 workers were members of sick clubs in the early 1890s and a significant minority in urban areas had access to dispensaries and medical missions, though cheap "6d doctoring" was often an alternative. ${ }^{24}$

Many people saw sick club cover as a sheer necessity, not least so as to avoid largely stigmatized Poor Law medical services, for the pauperizing effects of illness operated via the loss of earnings and the costs of medical

\footnotetext{
${ }^{17}$ They had 6.25 million members plus dependants by the early 1930 s and 10.3 million by 1938 . Steven Cherry, 'Before the National Health Service: financing the voluntary hospitals, 1900-1939', Econ. Hist. Rev., 1997, 50 (2): $305-26$, p. 318; and note 14 above.

${ }^{18}$ Idem, 'Accountability, entitlement and control issues and voluntary hospital funding c.1860-1939', Soc. Hist. Med.,1997, 9 (2): 215-33.

${ }^{19} \mathrm{Idem}$, 'Regional comparators in the funding and organisation of the voluntary hospital system, c.1860-1939', in Waddington and Hardy, op. cit., note 2 above. Aneurin Bevan was involved in such efforts in the Tredegar Medical Aid Society, which offered sick club hospital benefit at three pence per week. John Campbell, Nye Bevan and the mirage of British Socialism, London, Weidenfeld and Nicolson, 1987, p. 21.
}

\footnotetext{
${ }^{20}$ Mike Saks (ed.), Alternative medicine in Britain, Oxford, Clarendon Press, 1992; James Riley, Sick, not dead, Baltimore and London, Johns Hopkins University Press, 1997.

${ }^{21}$ J Frome Wilkinson, Mutual thrift, London, 1891, p. 191.

${ }^{22}$ David G Green, Working-class patients and the medical establishment, Aldershot, Gower, 1985 , p. 95. This includes some double counting because of dual policy holders.

${ }^{23}$ The battle of the clubs, London, Lancet, 1896, pp. 117, 123, 180.

${ }^{24}$ David Hamilton, The healers: a history of medicine in Scotland, Edinburgh, Canongate, 1981; Thomas Ferguson, The dawn of Scottish social welfare, Edinburgh, Nelson, 1948, pp. 443-4.
} 


\section{Hospital Saturday, Workplace Collections}

attention..$^{25}$ Yet popular interest in health care extended beyond economic necessity, the acceptance of charity or deference to the advocates of self-help. Preliminary findings that, "for primary health care services before the Great War the working classes took an active role in both the procurement of care for themselves and their families and in the management and control of those services" are steadily being reinforced. ${ }^{26}$

At first sight, the evidence for similar conclusions with regard to hospital care is much less compelling. Voluntary hospitals, particularly the teaching and more venerable institutions, had traditionalist, jealously-guarded systems of government. The extent to which medical influence and business or organizational skills were grafted on to these varied, but most were seen as "great conservative institutions ... dominated by their medical mandarins". ${ }^{27}$ These flagships of the voluntary movement had sailed untroubled by issues such as patients' rights or accountability to a general public but were increasingly disturbed by financial pressures. In 1857 the Statistical Society had estimated that 90 per cent of charitable spending on the sick poor in London was channelled via hospitals and that treatment costs per head at the endowed institutions, Guy's, St Thomas's and St Bartholomew's, were two to four times higher than in other general hospitals. ${ }^{28}$ These revelations had little impact until the cushioning effect of income from endowed lands deflated along with rental values in the agricultural depression of the 1870s and 1880s. Such income for Guy's Hospital fell to half the 1850 level by 1880 and, amid accusations of mismanagement, the Hospital successively resorted to bed closures, loans and paying patients between 1882 and $1884 .^{29}$ Along with St Thomas's, the London, Westminster, St George's, Middlesex and University College hospitals were all running deficits on annual accounts, selling assets or launching uncoordinated public appeals by then. But whether the preoccupations of metropolitan hospitals, particularly the endowed institutions, encompassed the situation outside London remains to be seen.

\section{Hospital Finances in the Late Nineteenth Century}

Rising costs represented a general problem for all the hospitals, though their experiences varied. In the teaching and larger general hospitals more advanced treatments were associated with new equipment, the establishment of special departments and enlarged medical staffs, including paid juniors responsible for dayto-day care. Hospital expansion often occurred against a backcloth of population pressure upon facilities, which meant increasing proportions of serious, accident or urgent cases, as seen at Manchester Royal Infirmary and the London Hospital. In

\footnotetext{
${ }^{25}$ See Cherry, op. cit., note 14 above, pp. $460-1$, for confirmation of this point in the relatively poor counties of Norfolk and Suffolk. Corresponding changes in attitudes to service users, and provincial emulation, lagged considerably behind the provisions of the 1867 Metropolitan Poor Act.

${ }^{26}$ Robert Earwicker, 'The emergence of a medical strategy in the Labour Movement
}

1906-19', Bull. soc. Hist. Med., 1981, 29: 6. Riley, op. cit., note 20 above, p. 20 , stresses the role of clubs as employers of doctors.

${ }^{27}$ Olive Checkland, Philanthropy in Victorian

Scotland, Edinburgh, John Donald, 1980, p. 162.

${ }^{28}$ Rivett, op. cit., note 4 above, pp. 112-13.

${ }^{29}$ H C Cameron, Mr Guy's Hospital

1726-1948, London and New York, Longmans, Green, 1954, p. 214. 


\section{Steven Cherry}

turn, the extended scope of surgery was producing greater risks of hospital infections and an upward trend in hospital deaths. ${ }^{30}$ These were partly combated by improved hygiene and antiseptic methods, but the cost of antiseptics and surgical gauze was mentioned specifically in financial inquiries, at Guy's for example. ${ }^{31}$ Higher standards in nursing were also required and, however controversial their implementation, the increased costs of more or better nurses and the facilities to accommodate them were universally recognized. Between 1866 and 1877 Addenbrooke's hospital governors were divided over rising household expenditure associated with existing nurses and domestic staff and the cost of salaries and appropriate accommodation for replacement "superior" nursing sisters, losing four matrons in the process. ${ }^{32}$ Nationally, over the 1860s and 1870s repeated outbreaks of hospital infections were also traced to defective design and construction. Rebuilding or relocation imposed heavy burdens on special funds, over $£ 450,000$ at the Edinburgh Royal, for example, and added to longer-term operating costs. ${ }^{33}$

Early attempts to monitor and compare the hospitals' performances were crude but revealing. Fleetwood Buckle's survey of 22 metropolitan hospitals in 1869 showed the need for the uniform presentation of accounts, an issue promptly addressed by Henry Burdett. ${ }^{34}$ The latter's examination of hospital expenditure patterns between 1876 and 1878 failed to resolve the problem of comparing patient costs in a central London teaching hospital with those in a small provincial infirmary. Nor were direct comparisons always valid, for example, that between the Leicester and Norwich hospitals when the latter was in the middle of a rebuilding programme with reduced patient admissions. Nevertheless, it was seen that patient costs per week varied from 11 to 45 shillings in similar hospitals with less than fifty beds. Very few hospitals exceeding 150 beds had average weekly patient costs outside a range between 15 and 30 shillings per week, though the Birmingham General, Edinburgh and Glasgow Royal infirmaries were low cost teaching institutions compared with most London hospitals and the Manchester Royal Infirmary. ${ }^{35} \mathrm{~A}$ third survey in 1890 confirmed these cost variations, but also revealed widespread increases of between 25 and 50 per cent over the period 1868 to 1889 , years in which the general price level tended to fall. ${ }^{36}$

Local attitudes to hospital treatment and the hospitals' own responses to their financial difficulties also varied. Campaigns against hospital abuse were fuelled by revelations that in London one-third, in Liverpool one-half and in Birmingham more than one-quarter of the population obtained free hospital treatment in the late

\footnotetext{
${ }^{30}$ Steven Cherry, 'The hospitals and population growth' Parts 1 and 2, Population Studies, 1980, 34 (1): 59-76, and (2), pp. 251-66.

${ }^{31}$ Cameron, op. cit, note 29 above, pp. 215-16,

${ }^{32}$ Arthur Rook, Margaret Carlton and W Graham Cannon, The history of Addenbrooke's Hospital, Cambridge, Cambridge University Press, 1991, pp. 192-4, p. 208.

${ }^{33}$ Cherry, op. cit., note 30 above, p. 75 . Of seven provincial hospitals examined, those in Manchester, Leeds and Norwich were completely
}

rebuilt and Leicester, Bristol and Worcester infirmaries much altered by 1880 . A Logan Turner, Story of a great hospital: the Royal Infirmary of Edinburgh 1729-1929, Edinburgh and London, Oliver and Boyd, 1937, p. 258.

${ }^{34}$ Rivett, op. cit., note 4 above, p. 115.

${ }^{35} \mathrm{H} \mathrm{C}$ Burdett, Hospitals and the state, London, Churchill, 1881, Appendices, pp. 16-19.

${ }^{36} \mathrm{H}$ C Burdett, Hospitals and asylums of the world, London, J and A Churchill, 1893, vol. 3, pp.172-3. 


\section{Hospital Saturday, Workplace Collections}

$1870 \mathrm{~s} .{ }^{37}$ Whilst demands for outpatient charges gathered momentum, the agenda of reformers in cities such as Manchester and Norwich also included the establishment of provident dispensaries. Hospital outpatient attendances increased at Bristol Royal Infirmary by more than one-fifth from the 1860 s to the 1870 s, but at the Manchester Royal and the Norfolk and Norwich they were reduced in the same proportion. ${ }^{38}$ The London Hospital was a noted free spender, which played upon its financial shortcomings to bolster appeals, compared with the more carefully managed St George's. A number of provincial hospitals, such as the Wolverhampton and North Staffordshire, the Leeds General and Norfolk and Norwich, were accused of "reckless and culpable extravagance" because their spending on new buildings was associated with apparent excess capacity, even though these hospitals were responding to structural defects and had relatively low numbers of outpatients. ${ }^{39}$ In contrast, a study of Glasgow Royal Infirmary, noting the build up of stocks and tight control of maintenance accounts, speculated that "the Infirmary's managers, who were preponderantly successful businessmen, could not rid themselves of the habit of profitability", substituting ploughback for profit. ${ }^{40}$

At a time when the hospital outpatients department often represented the first point of contact with formal medicine and when systems of referral from primary to secondary care were undeveloped, potential hospital users might be swayed by the availability of any charitable service rather than deterred by their fear of institutions. Increased usage of hospitals, even as club doctoring and GP services themselves assumed mass proportions, indicates an improving popular perception of hospital care, particularly in association with good nursing and rest. The Hospital commented positively in 1890 , "people often want food quite as much as medicine, but on account of the greatly superior medical attention they receive ... they prefer to go to the hospitals". ${ }^{41}$ This rationale was a prerequisite for grassroots effort to procure or organize hospital services. Doctors in special hospitals had often tried to build up demand, not least to justify their own skills and reputations, but the involvement of medical men and hospital administrators in efforts to promote popular support for hospital funding represented a new feature. Thomas Wright and James Wakley provided medical input in the promotion of the Birmingham and London Hospital Sunday funds respectively, and Henry Burdett's knowledge of the Hospital Saturday movement began when he was superintendent at Birmingham Queen's Hospital in 1869.42 "Demand-side" features thus complemented and partly reflected conventional, "supply" explanations, based upon the claims of researchbased, scientific medicine and rising standards of care, nursing and hygiene in the hospital environment.

With only fragmentary evidence of attitudes to hospital care, the extent and nature of support for hospital funding was an important indicator of more positive interest.

\footnotetext{
${ }^{37}$ Burdett, op. cit., note 35 above, p. 6.

${ }^{38}$ Steven Cherry, 'The hospitals and population growth', unpublished $\mathrm{PhD}$ thesis, University of East Anglia, 1976, pp.196, 224, 252.

${ }^{39}$ Burdett op. cit., note 35 above, p. 5. Cherry, op. cit, note 38 above, pp. 224, 252.
}

\footnotetext{
${ }^{40}$ Rona Caffney, 'The development of hospital provision in Glasgow between 1867 and 1897', PhD thesis, University of Glasgow, 1979, p. 103.

${ }^{41}$ Hospital, 18 Jan 1890, p. 243.

${ }^{42}$ Rivett, op. cit., note 4 above, p. 373.
} 


\section{Steven Cherry}

This reflected variable social contexts, particularly the local culture of philanthropic effort, in addition to the size, type and characteristics of the particular institution supported and the outlook of its governing authorities. Thus there is need for caution against summary and generalization, yet it is also important to attempt an overall description and suggest broader trends as well as exploring variations.

Along with subscriptions and donations, rent or interest from the hospitals' accumulations of land and investments was a traditional and regular income source, particularly for the older established institutions. Hospitals were reluctant to divulge the extent of such assets, which were also difficult to value with precision, but their total "invested property" was estimated at between $£ 7.5$ and $£ 10$ million in $1889 .{ }^{43}$ Income from these resources confirms the concentration of such wealth. Altogether $£ 175,000$ was received from endowments by Guy's, St Thomas's and St Bartholomew's hospitals that year. This dwarfed the $£ 35,000$ total for the other nine London hospitals with medical schools and the eleven provincial teaching hospitals' combined figure of $£ 37,000$, even though these had more diversified investments. ${ }^{44}$ In grouped terms, London teaching hospitals derived roughly 60 per cent of their ordinary income from investments and endowments over the late nineteenth century, compared with the 25 to 30 per cent return received by the teaching and larger general hospitals in the provinces. Scottish hospitals received fractionally less, but the Glasgow Royal Infirmary's investments exceeded $£ 115,000$ and yielded over $£ 4,500$ by 1890 , and this was barely half of similar receipts at the Edinburgh Royal. ${ }^{45}$

Of the irregular sources, special donations sometimes shaped the pattern of hospital development, as with the Whitworth and Lewis legacies in the location of the rebuilt Manchester Royal Infirmary, St Mary's, and Eye hospitals and cancer pavilion. ${ }^{46}$ They probably matched non-specified legacies, which were usually earmarked for capital accounts or projects rather than maintenance. Over time, a degree of predictability in legacies emerged and on average they represented about one-third of hospitals' ordinary income. ${ }^{47}$ London hospitals again fared better than the national average, receiving $£ 1.9$ million over the 1890 s, the special and teaching institutions doing particularly well (see Table 1). Legacies to provincial teaching hospitals exceeded $£ 400,000$ in the 1890 s, but this represented an annual average below $£ 4,000$ to each. The comparable figure for teaching hospitals in Scotland, where legacies almost matched all ordinary income sources, was $£ 13,000$. Edinburgh Royal Infirmary could count upon legacies and special funds averaging $£ 35,000$ annually over the 1890s, an amount some 50 per cent higher than the ordinary income at the largest hospitals in Manchester, Leeds or Birmingham at this time. ${ }^{48}$ Where philanthropic initiatives lay with great benefactors, hospitals could not expect equitable or informed distributions. Newer or minor provincial hospitals were likely to have smaller reserves and their "windfall" income was less predictable; consequently

\footnotetext{
${ }^{43}$ Burdett's hospital annual, London, Scientific Press, 1891, p. lix.

${ }^{44}$ Ibid., 1889, p. lxv.

${ }^{45}$ Ferguson, op. cit, note 24 above, p. 471.

${ }^{46}$ Pickstone, op. cit, note 12 above, pp 193-8.
}

\footnotetext{
${ }^{47}$ Recorded "ordinary" income at 160 hospitals in this period averaged $£ 1.17$ million, with legacies this was $£ 1.64$ million. Burdett's hospital annual, op. cit., note 43 above. From 1893 this became Burdett's hospitals and charities. ${ }^{48}$ Ibid., 1890-1900.
} 


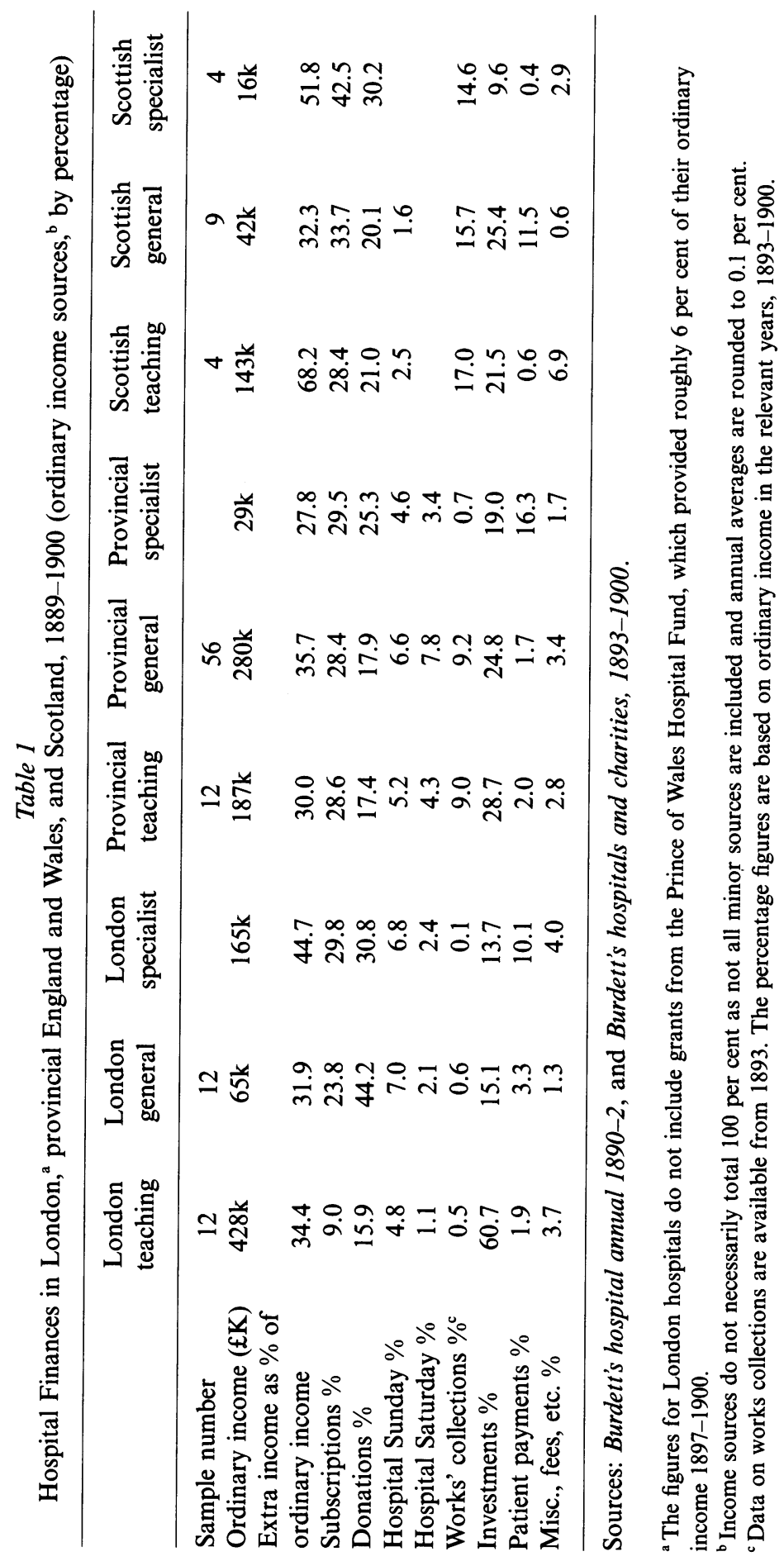




\section{Steven Cherry}

their administrators needed to address any new financial opportunity from the outset. As will be seen, this often extended to forms of recognition for workers' contributions.

The table summarizes data compiled by Burdett's hospital annual, later Burdett's hospitals and charities, the principal statistical source from 1889-1900. It cannot show the dynamics of late-nineteenth-century trends in voluntary hospital funding, though it indicates the extent of new developments by 1900. Among the latter, Hospital Sunday provided between 4 and 7 per cent of hospitals' ordinary income in England and Wales and slightly less in Scotland by the 1890s. Hospital Saturday was already a more important source in the provinces, particularly for the larger non-teaching general hospitals. Workplace collections were also developing: they counted for little in London, but provided nearly one-tenth of provincial and onesixth of Scottish hospitals' ordinary income on average. ${ }^{49}$ Often regarded as a new, popular form of philanthropic effort, direct payments by patients also featured in special hospitals and in Scottish general hospitals. ${ }^{50}$ Among the "miscellaneous" sources, the Prince of Wales Hospital Fund rapidly assumed importance in London hospitals from 1897 and nurse probationers' fees and income from nursing services were significant, particularly in teaching hospitals.

\section{Hospital Sunday, Hospital Saturday and Works Collections}

The preaching of church sermons, usually followed by an appeal or collection, often promoted or marked the establishment of hospitals in the eighteenth century. Although church and chapel hospital collections were regular or periodic, they were first systematized into an annual Sunday event on an area basis in Birmingham in 1859. This was rapidly emulated and further innovation came after 1873 with attempts to centralize and channel metropolitan Hospital Sunday funds, rewarding hospitals on the basis of costs per bed and comparative utility. Keir Waddington has re-examined these developments, but the present study emphasizes three features. ${ }^{51}$ First, the overall influence of Hospital Sunday can be overstated. On average, $£ 34,000$ was distributed annually to London hospitals from 1873 to 1897 and collections exceeded $£ 50,000$ by 1900 but these were buoyed up by several large donations, exceeding $£ 10,000$ in 1899 , for example. ${ }^{52}$ Second, as a proportion of provincial hospital income, Sunday funding had peaked by 1900 and tended to be lower in Scottish hospitals. Third, the importance of centralized distribution counted for less outside London and the main provincial cities, with several voluntary institutions competing for resources, and any interventionist role in the capital was

\footnotetext{
${ }^{49}$ Burdett recorded works collections of $£ 73,000$ in 35 English and Welsh towns in 1891 . Not all this money was allocated to hospitals, but the sample omitted strong collecting areas such as Bradford, Leicester, Halifax and Wigan. Burdett's hospital annual, op. cit., note 43 above, and Burdett, op. cit., note 36 above, pp. 213-14.

${ }^{50}$ Calculations from The Hospitals Year Book, $1937-41$ indicate that 'Patients and societies' provided over 38 per cent of ordinary income in
}

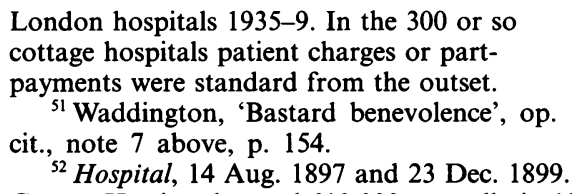

London hospitals $1935-9$. In the 300 or so cottage hospitals patient charges or partpayments were standard from the outset.

${ }^{51}$ Waddington, 'Bastard benevolence', op. cit., note 7 above, p. 154 .

${ }_{52}$ Hospital, 14 Aug. 1897 and 23 Dec. 1899.

George Herring donated $£ 10,000$ annually in 1899 and 1900 and, beginning in 1901 offered a 25 per cent bonus on every $£ 1,000$ collected by Hospital Sunday. 


\section{Hospital Saturday, Workplace Collections}

largely usurped after 1897 by the Prince of Wales/King Edward's Hospital Fund, which commanded greater resources. ${ }^{53}$ Thus, apart from specific instances of joint Sunday and Saturday collections, it is difficult to see where the Sunday Fund moved beyond the middle classes and their concerns. ${ }^{54}$

Hospital Saturday had diverse origins, in house to house and street collections, in donations and fund-raising by friendly societies, conjointly with Hospital Sunday and in workplace collections. ${ }^{55}$ Such effort was initially presented as a diminutive of the Sunday Funds, with fund-raising for hospitals as the primary objective, a welcome relief from reliance upon medical charities and a worthy exercise in self-help. ${ }^{56}$ In turn, the Saturday movement was given more prominence than workplace collections. Yet in England and Wales sporadic collections can be traced back as early as 1822 in Leicester, where factory workers raised their own subscriptions to the infirmary, and 1825 in Bradford. ${ }^{57}$ Regular collections in the north-east, West Midlands, south Yorkshire and Humberside and the Lancashire cotton towns all predated Hospital Saturday. ${ }^{58}$ In the late 1880 s Saturday fund-raising featured in more than forty English provincial centres and, apart from recent examples in southern counties, workplace collections were prominent, many now systematized around a halfpenny or penny per week contribution. ${ }^{59}$ Regular works collections in Scotland began in Dundee before 1820, on Clydeside in the early 1830s and in Edinburgh by 1850 . These remained the norm, with the introduction of Hospital Saturday in Aberdeen in 1896 a comparatively unusual event. ${ }^{60}$

Estimating the aggregate funds allocated to the hospitals from Saturday and works collections is difficult. Burdett's sample of mainland British hospitals suggests a figure of $£ 85,000$ in 1893 , when works collections are identified for the first time, rising to $£ 109,000$ in 1900 , but this understates the collecting effort by roughly onefifth. ${ }^{61}$ Further amounts often featured under the traditional headings of "donations"

\footnotetext{
${ }^{53}$ The Prince's Fund primarily dealt with grants to hospital capital accounts, but its initial contribution to London hospitals' ordinary income exceeded the Sunday Fund. Owen, op. cit., note 9 above, p. 486.

${ }^{54}$ Rivett, op. cit., note 4 above, described the Sunday Fund as "essentially a middle and upper class organisation which ran an annual collection on a Sunday in June”, p. 123.

${ }^{55}$ The first Hospital Saturday was held in Coventry in 1870 , followed by Merseyside and Manchester in 1871 and 1872. The latter and Norwich (1873) were conjoint with Hospital Sunday, Birmingham (1873) was more independent.

${ }^{56}$ Burdett's hospitals and charities, 1914, p.131, still focused upon aims "to collect funds ... to inculcate the principles of self and mutual help ... to manage their own affairs".

${ }^{57}$ E Frizelle and J Martin, The Leicester Royal Infirmary 1771-1971, Leicester, No.1 Hospital Management Committee, 1971, p. 152. Hardy's factory workmen subscribed 2 guineas annually from 1822. Bradford reference in Gordon Palliser
}

et al., The charitable work of hospital contributory schemes, Bristol, British Hospitals Contributory Schemes Association, 1984, p. 38.

${ }^{58}$ For example in Middlesbrough (1859) and Sunderland (1861); Hull (1861) and Barnsley (1865); Preston and Blackburn (1860s), Birmingham and Wolverhampton (1860s).

${ }^{59}$ Exeter (1874) and Gravesend (1879) were among the early southern outposts of Saturday funding.

60 'Workpeople in mills', Dundee Royal Infirmary annual reports by 1822 , in $\mathrm{H} \mathbf{J}$ Gibson, Dundee Royal Infirmary 1798-1948, Dundee, 1948 , p. 25 . "General trades" and friendly societies in Greenock 1832, in J Ferrier, The Greenock Infirmary 1806-1968, Greenock and District Hospitals Board of Management, 1968, p. 38.

${ }^{61}$ For example, $£ 42,000$ was allocated to hospitals in 22 provincial centres where Saturday and works collections are recorded in $\mathbf{1 8 9 0 .}$ Comparable figures, based on 50 provincial hospitals, were $£ 80,000$ in 1893 and $£ 103,000$ in 1900 . These assume virtually no Saturday or 


\section{Steven Cherry}

or occasionally under "subscriptions", as in Birmingham and Edinburgh. They frequently comprised the majority of Joint Hospital Sunday and Saturday Funds, from the outset in Bradford or by 1900 on Merseyside, for example. Large works collections were sometimes included within Sunday funding, as in Newcastle where "Sunday" totals in the mid-1890s included over $£ 2,000$ collected annually from Armstrong's engineering workers. ${ }^{62}$

Yet even if the aggregate totals for Saturday and works collections are underestimated, at national levels they apparently provided only a small portion of hospital income. However, their significance was as a new and developing source of regular income, albeit with great regional variance. Bald information on individual hospitals is provided in the Appendices and, with the regional examples discussed below, suggests that some hospitals already relied heavily upon this source. Equally important, the different social base of this fund-raising was likely to carry major implications for hospital authorities, for the culture of philanthropic effort and the expectations of the new donors.

\section{Regional Examples: the North-West and Midlands}

In the towns around Manchester the attitude of local social elites generally determined the size, if not the existence, of local hospital facilities. But Pickstone also noted workers' involvement in social alliances, with medical practitioners in the establishment of hospitals in Bolton and Rochdale, or with principal employers, as in Blackburn and Wigan, by $1880 .^{63}$ Large employers could play a paternalist philanthropic role in providing the physical fabric of a hospital, but Saturday and workplace collections were often important, particularly in the transition from dispensary to casualty hospital facilities. Local elites were prepared to enhance hospital facilities particularly when running costs could be met through regular income. As is clear from Appendix 1, works collections in towns such as Bolton, Preston or Wigan sometimes amounted to the lion's share of income to the local hospital. They suggest the involvement of many thousands of regular contributors and over the 1890 s were sufficient to allow some diversification into convalescent and nursing facilities. ${ }^{64}$

In contrast, a relatively poor performance might indicate continuing reliance upon

collecting effort south of a line between Bristol and Suffolk, excluding London. Even assuming no underestimation in Burdett's London or Scottish data, the revised 1893 total rises to $£ 101,000$ (plus 19 per cent) and that for 1900 to $£ 132,000$ (plus 21 per cent). Burdett, op. cit., note 36 above; Burdett's hospitals and charities, 1893, 1900. Additional provincial information from Cherry, op. cit., note 17 above, and from Palliser et al., op. cit., note 57 above.

${ }^{62}$ Hospital, 4 Nov. 1899.

${ }^{63}$ Pickstone, op. cit., note 12 above, p. 144 , identifies as the critical factors employer paternalism, the strength of the local middle class and its suspicion of the medical profession, and the presence of concentrations of workers familiar with benevolent funds.

${ }^{64}$ From 1872 the Wigan Hospital Saturday network provided almost $\mathbf{4 0}$ per cent of local hospital income. By the late 1880 s halfpenny or penny schemes provided $£ 1,400$ in Bolton, $£ 1,800$ in Preston, and $£ 2,500$ in Blackburn for local hospitals, between one-third and half their ordinary income. Pickstone, op. cit. note 12 above, p. 45 (Wigan); Burdett, op. cit., note 36 above, pp. 213-14 (Blackburn); Palliser, op. cit., note 57 above (Bolton); John Wilkinson, Preston's Royal Infirmary, Preston, Carnegie, 1987, p. 45. 
traditional charity, an inclination to alternative medicines and healing or to the provident dispensary model, or an unwillingness to accept a diminished, patronized role at the hands of social superiors. The rise of provident dispensaries in the townships of Manchester has already been noted but the subordination of workplace and street collections within the Sunday Fund, with only a "workmen's auxiliary" from 1895 may have been counterproductive. Less than $£ 1,000$ was collected for the two main hospitals in 1900, though special hospitals, smaller district hospitals and dispensaries also competed for the limited funds collected. ${ }^{65}$ Years later, Manchester was described as "scandalously behind other cities ... in support of its hospitals" and as "a backwards centre" in the collecting and contributory scheme movement. ${ }^{66}$ The Joint Saturday and Sunday Fund established in 1870 on Merseyside did better, the "Saturday" element soon providing $£ 3,000$ annually and over $£ 7,000$ by 1900 , exceeding Sunday funding. ${ }^{67}$

How important was workplace funding outside the north-west? The influence of Liberalism may help to explain relatively low levels of hospital facilities proportionate to population in Birmingham in the third quarter of the nineteenth century. Income from invested funds, a reasonable indicator of the size of such assets, for the Birmingham hospitals was less than in Leeds or Glasgow and was far below that for the Manchester or Edinburgh Royal Infirmaries. An Artisans Medical Charities Committee supported Birmingham hospitals in the 1860s and the Workingmen's Fund was established in 1869 to assist the Queen's Hospital extension. The latter was based upon "a committee of 800 representatives of labour" and prompted by the surgeon Sampson Gamgee and hospital secretary Henry Burdett. ${ }^{6}$ An amalgamation produced the Hospital Saturday Fund in January 1873, which then demonstrated its capacity for growth and initiative. Collections and appeals for the equivalent of one Saturday afternoon overtime payment per year produced $£ 4,000$ for local hospitals initially, but the introduction of a penny per week scheme in 1878 proved decisive. Almost $£ 11,000$ was raised in 1891 , suggesting a contributing membership exceeding 50,000, with money distributed to the Queen's, General, Eye and Children's hospitals and the dispensary. ${ }^{69}$ That year the Fund became a registered company and diversified, providing surgical aids, donations to the District Nursing Association, an ambulance service, convalescent home facilities and, eventually, its own consultant physician. Roughly $£ 7,000$ of the $£ 18,000$ raised in 1898 was retained for these new services, but hospital allocations provided 22 per cent of the Queen's Hospital's ordinary income and 14 per cent of that at the larger Birmingham General Hospital. ${ }^{70}$ 140-1.

${ }^{65}$ Pickstone, op. cit., note 12 above, pp.

${ }^{66}$ Hospital, 17 April 1920, p.56; Hospital and Health Review, 1923, 21, p. 266.

${ }^{67}$ Hospital, 9 Dec. 1899 and 27 Jan. 1900. This was almost 25 per cent of ordinary income at the four main hospitals in 1900, with Sunday funding providing a further 20 per cent.

${ }^{68}$ Joseph Sampson Gamgee, The origin and future of Hospital Saturday, Birmingham, W G Moore, 1882, pp. 5, 7.

\footnotetext{
${ }^{69}$ At fifty weekly 1d contributions, each $£ 1,000$ raised represented roughly 4,800 contributors.

${ }^{70}$ Hospital, 21 Oct. 1899, Burdett's hospitals and charities, 1898, p. 109. By 1880 the Fund covered 35 per cent of running costs at the Women's hospital and a $£ 500$ annual grant to the Children's hospital. Gamgee, op. cit., note 68 above, p. 7 .
} 


\section{Steven Cherry}

In other industrial Midlands towns where workers' fund-raising focused upon a particular hospital substantially greater contributions were made. At the North Staffordshire Hospital in the early 1880 s, "the potters not only pay by their contributions for all the expenses entailed by the treatment at the hospital of members of their class, but they present in addition a considerable sum ... to help to pay for the medical relief of the sick and friendless who are absolutely dependent on charity" ${ }^{71}$ Saturday funding based on works collections involved over 10,000 donors in Leicester and Wolverhampton and perhaps 7,000 in Coventry and provided respectively 25,43 and 32 per cent of the local hospital's ordinary income by $1891 .{ }^{72}$

\section{Yorkshire Studies}

Hilary Marland's study suggests that in Huddersfield employers' support featured prominently in the transition from dispensary to hospital facilities. Wakefield was less industrialized and the professional and middle classes were less enthusiastic about hospital facilities, which developed later and relied heavily upon the gesture of Thomas Clayton. ${ }^{73}$ In both towns working-class effort was primarily directed at friendly society and club medicine. Marland focuses upon the years before 1870 but acknowledges the beginnings of Hospital Saturday. In 1875 this provided 24 per cent of the Clayton Hospital's income and 9 per cent at the larger Huddersfield Infirmary, involving respectively 120 and 110 workplaces by $1880-1 .{ }^{74}$ In both cases the extension of worker interest in hospital funding was under way, with greater contributions by 1900 apparent in Appendix 1 below.

This interest was general throughout industrial Yorkshire, though with significant variations. In Sheffield neither the Sunday nor Saturday movements met with early success. Local rivalries featured strongly, for the initial proposals for Hospital Sunday collections in 1867 came from the Royal Hospital, the former dispensary, which was completing its new buildings but was unable to open and maintain roughly 30 per cent of its bed capacity. Its action further antagonized supporters of the older Royal Infirmary, a problem repeated in the false start of the Saturday collections in $1873 .^{75}$ But a further issue in the stalling of the Saturday Fund was that both hospitals insisted that "such collections should be free gifts without privileges or ... forms of recommendation" ${ }^{76}$ The Sunday Fund also failed to realize its potential, for it was acknowledged "how the collections have fallen since 1891, notwithstanding the large

\footnotetext{
${ }^{71}$ Henry Burdett, Hospital Sunday and Hospital Saturday, London, Churchill, 1884, p. 23.

${ }^{72}$ Calculated from Burdett's hospitals and charities, 1891, p. 1xxxix. Membership estimates are based on allocations to the hospitals, not the totals collected and are therefore low. Frizelle and Martin, op. cit., note 57 above, pp. 169-71 (Leicester); Palliser, op. cit., note 57 above (Wolverhampton), and D T Tugwood, The Coventry and Warwickshire Hospital 1838-1938, Lewes, Book Guild, 1987, pp. 40-4.
}

\footnotetext{
${ }^{73}$ Marland, op. cit., note 13 above, pp. $130-4$.

${ }^{74}$ Ibid., pp. 101, 158-9.

${ }^{75}$ Sheffield Hospital Sunday Fund Minute Book, 1 Nov. 1867, Sheffield Archive 33H 25/1; Hospital Saturday, Sept. 1873, Archive JC 1364. Rival proposals, "to get the working men to make small deposits every Saturday night and so establish a provident dispensary" were rejected on the grounds of overlap with existing sick clubs.

${ }^{76}$ Ibid. Sunday Fund, 1 Nov. 1867.
} 


\section{Hospital Saturday, Workplace Collections}

increase in the population of the city", and the issue of recommendations was reopened in $1898 .^{77}$ By then Sunday and Saturday fund-raising for both hospitals was well below the direct workshop collections of $£ 3,100$ provided for the Royal Infirmary. ${ }^{78}$

Did the latter benefit because it was the city's teaching hospital, perceived as more advanced or worthy of support? The experience of Leeds suggests not. Here was another example of works collections within a joint Saturday and Sunday fund having an early, but modest start. Less than $£ 1,000$ was raised annually until 1886 , when a distinct workpeople's section was formed. Equally important, the General Infirmary, which was also a teaching hospital, accepted that the dispensary and other hospitals in the area should also benefit from workers' fund-raising provided that it suffered no diminution in cash allocations. Within four years collections had quadrupled to provide almost one-quarter of the Infirmary's ordinary income and a similar proportion to the Women's and Children's Hospital over the next decade. ${ }^{79}$

In the south Yorkshire colliery or steel towns workers were often involved from the outset in hospital building. This was the case in Barnsley (1867), Rotherham (1872) and Mexborough (1889), by which latter date the Chesterfield Infirmary (1855) was also "largely supported by workingmen" ${ }^{80}$ Such effort cannot be explained solely by deference to paternalistic employers or hospital authorities. The South Yorkshire Miners Association and Friendly Societies featured strongly in the joint Saturday and Sunday movement in Barnsley and, with direct workplace collections, provided roughly 60 per cent of the local hospitals' income in the late 1880s and half the establishment costs of a new children's ward in $1898 .{ }^{81}$ Although its annual reports frequently cast the hospital as "the pet charity" of the district and played upon community pride in praising the comparative strength of local collecting efforts, the workers' contributions represented more than a simple philanthropic exercise. The hospital was persuaded to extend subscriber-recommendation rights in 1890 and one-third of patients were then referred by workplace schemes and the Saturday and Sunday fund. But when the Committee of Management then sought to restrain such recommendations, it promptly received "intimations ... that ... the money will be sent elsewhere or not collected at all" and the allocated funds fell by one-third ${ }^{82}$

In Rotherham, works collections provided one-sixth of the hospital's establishment costs and one-fifth of ordinary income in its first year. Emphasis upon the local community and a direct, open "appeal to the workers ... that all may contribute

\footnotetext{
${ }^{77}$ Ibid. Sunday Fund, 13 Dec. 1907; 25 Nov. 1898. The referral of patients by the Sunday Fund had been "favourably considered" by local hospitals from 10 Dec. 1897. There were also subsequent allegations that substantial deductions had been made from Sunday Fund money by local clergymen (21 Dec. 1910).

${ }^{78}$ Burdett's hospitals and charities, 1900 , p. 115. The Jessop Hospital for Women and the Royal Hospital received direct collections in 1901.

${ }^{79} \mathrm{~S} \mathrm{~T}$ Anning, The General Infirmary at Leeds, Edinburgh and London, E \& S Livingstone,
}

1966, p. 106; Burdett, op. cit., note 47 above, 1900. In other mill towns, works collections comprised a major element of hospital income in Bradford, Dewsbury, Halifax, Keighley and Wakefield, slightly less so in Huddersfield.

${ }^{80}$ Burdett's hospital annual, op. cit., note 43 above, 1891, p. 10.

${ }^{81}$ Barnsley Beckett Hospital, Annual reports, 1885-95, 1898-1901.

${ }^{82}$ Ibid., 1899-1900; namely $£ 800$ compared with the usual $£ 1,150$ to $£ 1,200$ of the late 1890s. 


\section{Steven Cherry}

... on some systematic plan approved of by themselves" doubled this proportion over the 1880 s and $1890 \mathrm{~s}^{83}$ The nearby Mexborough Montagu Hospital originated in a delegation of miners and gasworkers to a sympathetic landowner, who offered a site and initial accommodation, whilst a halfpenny scheme sufficed to run this expanding cottage hospital. ${ }^{84}$ In these three cases, workers were more actively involved than in Pickstone's suggested model of employer paternalism; in a fourth-the Doncaster Infirmary-it was the employers who in 1875 refused to co-operate by making weekly deductions from wages. Consequently, the planned 1d per week scheme was postponed, though Saturday and works collections still represented 17 per cent of the Infirmary's ordinary income before 1900. A wider struggle ensued, in which the Yorkshire Miners Association was eventually able to gain the support of the Infirmary medical staff for its plans for a larger and relocated hospital. ${ }^{85}$

\section{The North-East and Scotland}

The record of workplace fund-raising in industrial Yorkshire was more than matched in the north-east. Sunderland was an exemplary model, for local collections assisted the replacement of the town dispensary with a general infirmary in 1867, met more than one-third of its running costs within ten years, and provided almost two-thirds of its ordinary income by $1900 .^{86}$ The Infirmary's decision to abolish individual subscriber-recommendation in 1877 reflected a growing sense of financial security and was evidently rewarded by enhanced workers' support. If the location of new hospitals in the north-east was influenced by the presence of substantial places of employment and the prominence of accident cases, this was not wholly determined by the employers' agenda. Workers' fund-raising was always enthusiastic and substantial, whether the hospital in question was a well-established teaching institution (Newcastle Royal Infirmary), associated with different religious faiths (North Ormesby and North Riding hospitals), or a particular employment (Eston) ${ }^{87}$ In Darlington the protracted completion of modest hospital buildings in 1884 no indicator of philanthropic largesse - and the meeting of running costs were achieved

\footnotetext{
${ }^{83}$ Rotherham Hospital and Dispensary, Annual reports, 1872 , p. 11, and 1880-99.

${ }^{84}$ This scheme still covered 55 per cent of the running costs of the relocated 48-bed hospital in 1914. Mexborough Montagu Hospital, Annual reports, 1909-14, and D M Wilson, $A$ short history of the Montagu Hospital Mexborough 1889-1925, Mexborough n/d.

${ }^{85} \mathrm{G}$ Swann, The Doncaster Royal Infirmary 1792-1972, Doncaster Hospital Management Committee, 1973, pp. 114-16; Doncaster Infirmary, Annual report, 1919, p. 20.

${ }^{86} \mathrm{~W}$ Robinson, The story of the Royal Infirmary, Sunderland, Sunderland, 1934, p. 77, p. 81 . The works collections suggest over 20,000 regular contributors by 1890 . See Appendix 1 .
}

\footnotetext{
${ }^{87}$ Works collections in Newcastle in 1900 were $£ 4,908$, with the Saturday fund $£ 1,300$, and the Armstrong's collection of roughly $£ 2,000$, when the Royal Infirmary ordinary income totalled $£ 14,711$. At North Ormesby Hospital, nursed by a Roman Catholic sisterhood, a halfpenny weekly collection provided 23 per cent of ordinary income in 1860 , and the penny version 44 per cent in 1882. Geoffrey Stout, History of North Ormesby Hospital 1858-1948, Stokesley, G Stout, 1989, pp. 27, 76. North Riding Hospital was established in 1861 and Eston Hospital in 1884 on the basis of direct deductions from ironstone miners' wages.
} 


\section{Hospital Saturday, Workplace Collections}

largely because of "the systematic manner in which the workmen of the town contribute to the funds". 88

Given the importance of legacies and accumulated funds to the older infirmaries of Edinburgh and Glasgow and the absence of an industrial hinterland at hospitals such as the Dumfries and Galloway (1776) or the Royal Northern, Inverness (1804), workplace funding was likely to be proportionately low in Scottish hospital incomes. Nevertheless, early and significant contributions occurred. Collections from "operatives and seamen" in Glasgow involved over 100 workplaces by 1850 and provided 10 per cent of the Royal Infirmary's ordinary income. ${ }^{89}$ From the early 1860s until 1900 the proportion from these sources fluctuated between 28 and 36 per cent, subject to economic cycles and the claims of newer hospitals in the area. ${ }^{90}$ Corresponding figures for the Western Infirmary rose from 17 per cent in the mid1870s to 27 per cent in the late 1890s, and averaged 24 per cent at Victoria Infirmary over the $1890 \mathrm{~s} .{ }^{91}$ In contrast, congregational or district collections were the model in Edinburgh itself, with fund-raising by coal and oilshale miners usually classed within "subscriptions and smaller donations". Direct contributions from the Lothian coalfields were "on a somewhat limited scale ... with a moderate degree of success" from 1849 , though separately recorded works collections exceeded $£ 4,500$ annually by the middle 1890 s, which represented 15 per cent of ordinary income for the Royal Infirmary.92

Similar proportions were raised at the Aberdeen Royal and Kilmarnock infirmaries by $1900 .{ }^{93}$ In Dundee, however, workplace collections provided one-tenth of infirmary income from the 1820 s and 1830 s, rising to one-quarter by the middle 1890 s, with further contributions from a well organized Hospital Sunday effort. ${ }^{94}$ Smaller and newer hospitals eventually attracted similar support, as in Leith (1848) where "workmen etc." were recorded among subscribers by 1869 and Stirling (1874), where the expansion of coalmining eventually produced financial support to accompany the accident cases..$^{95}$ When Falkirk cottage hospital opened in 1889 "a very large number of the working classes inspected the building" and this was followed by penny weekly collections which helped to support further extensions in $1900 .{ }^{96}$ Summary introductions in Burdett's hospitals and charities for Scottish hospitals,

\footnotetext{
${ }^{88}$ Hospital, 2 Nov. 1889, p. 72.

${ }^{89} \mathrm{~J}$ Jenkinson, M Moss and I Russell, The Royal: the history of the Glasgow Royal Infirmary 1794-1994, Glasgow Royal Infirmary NHS Trust, 1994 , p. 67.

${ }^{90}$ Calculated from Caffney, op. cit, note 40 above, Tables III, IV and V, pp. 75-6. I wish to acknowledge and draw attention to this important source, to which I have added 1897-1900 material from Burdett's hospitals and charities in Appendix 2.

${ }^{91}$ Annual Hospital Sunday and church subscriptions were roughly $£ 2,000$ in the 1870 s and 1880 s but growing from 1895 .

${ }^{92}$ Logan Turner, op. cit., note 33 above, pp. 221-3. The annual average of $£ 4,550$ is from Burdett, op. cit., note 47 above, 1893-5.
}

\footnotetext{
${ }^{93}$ Burdett's hospitals and charities, 1893-1900. Works collections in Aberdeen still exceeded the Hospital Saturday effort. Hospital, 3 Feb. 1900 (Kilmarnock).

${ }^{94}$ Gibson, op. cit., note 60 above, pp. 25, 27; Burdett's hospitals and charities, 1893-5.

${ }_{95}$ D H Boyd, Leith Hospital 1848-1988, Edinburgh, Scottish Academic Press, 1990, p.19; W G Harrington, Stirling Royal Infirmary 1874-1974, Stirling, Royal Infirmary, 1974, p. 16.

${ }^{96}$ I Scott, Touch ane touch a'; Falkirk and District Royal Infirmary 1889-1989, Falkirk, Forth Valley Health Board, 1990, pp. 4-5.
} 


\section{Steven Cherry}

admittedly based upon a sample of just seventeen but including the four teaching institutions, suggest that works collections provided nearly 17 per cent of their ordinary income between 1889 and $1900 .{ }^{97}$

\section{London: The Exception not the Rule}

London's Saturday Fund never remotely assumed the financial significance to hospitals seen in the examples above. It began in 1873 and focused upon collections in the streets and public places, raising nearly $£ 9,000$ annually within a decade. ${ }^{98}$ Almost $£ 5,000$ was distributed to general hospitals and nearly $£ 4,000$ to special hospitals each year in the $1890 \mathrm{~s}$, respectively just 1.25 per cent and 2.40 per cent of their ordinary income. The inaugural London Saturday Fund Journal recorded workplace collections but noted "a knowledge of the subscribing capacity of these establishments (leaving out the Arsenal and Post Office) will at once reveal that the positions of some should be altered" ${ }^{99}$ One or two hospitals did have a community or industrial base. Poplar hospital, very much associated with the docks and accident cases, was "to a large extent supported by the subscriptions and efforts of the workingmen themselves" and through works collections and subscriptions "made up jointly by employers and employed" ${ }^{100}$ Other workplace collections also bypassed the Saturday Fund and helped the London and University College hospitals directly, but these averaged only $£ 2,900$ annually between 1893 and $1900 .{ }^{101}$

Crude comparisons of Saturday funding efforts placed the London organization in a poor light, for less than $£ 5$ per thousand population was raised in the capital in 1891, a figure often quadrupled in a swathe of northern and Midlands industrial towns and cities. ${ }^{102}$ Explanations for this relative lack of success must recognize the alternative philanthropic resources available in London, the number of hospitals competing for attention, the great endowed resources of some and the highly publicized financial crises of others. ${ }^{103}$ Each factor was likely to prove daunting to more modest collecting efforts. A relative paucity of large workplaces capable of producing core funding was allegedly a problem in London, though not an insurmountable one given Birmingham's experience, while the central distribution of Saturday funding across metropolitan hospitals necessarily implied thin resources for each.

The lack of interest in hospitals and the alleged "abuse" of their facilities by the poor and comfortable alike preoccupied hospital reformers in the 1870 s and 1880 s,

\footnotetext{
${ }^{97}$ Based mainly on the largest 12 general hospitals and 5 others, from 21 special and 29 cottage or village hospitals open in 1890 .

${ }^{98}$ Gamgee, op. cit., note 68 above, p. 1; Burdett, op. cit., note 71 above, p. 23.

${ }^{99}$ Hospital Saturday Fund Journal, 1 March 1893 , p. 2. That year only 23 workplaces collected more than $£ 50$.

${ }^{100}$ Hospital, 7 Dec. 1889 , p. 159.

${ }^{101}$ Such collections constituted roughly 9 per cent of Poplar Hospital's ordinary income and 4
}

\author{
per cent that of the much larger London \\ Hospital. Burdett's hospitals and charities, 1900, p. \\ 275. \\ ${ }^{102}$ Ibid., 1893. The figure of $£ 19$ per 1000 \\ population was exceeded in most towns so far \\ examined, barring Leeds where it was $£ 15$ per \\ 1000. Colchester and Exeter were the sole \\ examples outside the north and Midlands \\ exceeding $£ 19$ per 1000 . \\ ${ }^{103}$ Owen, op. cit., note 9 above, pp. 477-9.
}




\section{Hospital Saturday, Workplace Collections}

and the performance of the Saturday Fund itself became the subject of public debate. ${ }^{104}$ Its organization of collections was bureaucratic and cumbersome: of the $£ 20,333$ raised in $1889, £ 2,961$ was deducted for expenses. ${ }^{105}$ Workplace fund-raising met employer resistance and "must hardly ever be done openly before the foremen or employers". ${ }^{106}$ Street collections required large numbers of people-over 3,000 to gather $£ 6,000$ in 1893 for example. ${ }^{107}$ This gave rise to concerns, including police complaints, not just about charitable abuse but also public disorder, charges which culminated in the Jubilee Year $1897 .{ }^{108}$ Reginald Acland, the Fund's Chairman, acknowledged the unreliability of such methods, but a series of meetings was required to produce the decision to end street collections and secure employers' support for workplace collections based on the penny a week format. ${ }^{109}$ The latter were successful, rising from $£ 10,000$ to $£ 17,000$ between 1897 and 1899 , though they barely compensated for the lost street collections. Further growth into the twentieth century was at low rates and the Saturday Fund now faced direct competition from the League of Mercy, a more compliant workers' fund-raising body established by the King's Fund in 1899. ${ }^{110}$

Although the Saturday Fund's contribution to metropolitan hospitals was eclipsed by the Prince of Wales/King Edward's Hospital Fund after 1897, the movement nevertheless had resources to command and its use of these indicates interests other than fund-raising. Robert Frewer, Secretary of the Fund in 1884, made no apologies for its selective distribution. Some hospitals did not deserve help; "the fact that the management of certain hospitals went by default was well known to the Committee". ${ }^{111}$ The Fund wished to recommend members for treatment and would reward hospitals offering quid pro quo; "Why should ordinary subscribers be supplied with them [letters of recommendation] and working men denied them? No greater mistake had been made than to meet the working men and women of London with this denial". ${ }^{112}$ Further, it sought influence in decision-making, asking whether hospital authorities would "refuse our contributions for the sake of denying us any share in the management of institutions ... in which we are more interested than any other class?". ${ }^{113}$

The author of such questions, according to voluntarist advocates, "proves beyond

\footnotetext{
${ }^{104}$ Burdett, op. cit., note 71 above, dismissed the Saturday Fund and its organizers: it was "such a failure" and should be absorbed by the Sunday Fund, "by far the more representative and important body", pp. 5, 16.

${ }^{105}$ Burdett's hospital annual, op. cit., note 43 above, p. cvxi.

${ }^{106}$ Letter from Mr Allam to the Charity

Record, 19 June 1884, cited in Burdett, op. cit., note 71 above, p. 3 .

${ }^{107}$ Medical Times and Hospital Gazette, 15 July 1893.

${ }^{108}$ Hospital, 3 and 17 April 1897, 30 Oct. and 11 Dec. 1897. This was not confined to London. In Newcastle, "Hospital Saturday ended in a fracas, during which ex-Mayor Whittingham assaulted one of his fellow workers ... the whole
}

proceedings in the police court showed what at best can be called an undignified meeting", Hospital, 12 July 1890, p. 216.

${ }^{109}$ Hospital, 18 Dec. 1897.

${ }^{110}$ Frank Prochaska, The voluntary impulse: philanthropy in modern Britain, London, Faber and Faber, 1988, p. 28.

${ }^{111}$ Frewer's contribution to a meeting of the Hospital Association, 21 May 1884, was appended to Burdett, op. cit., note 71 above, p. 26.

${ }^{112}$ Frewer cited a friendly society or trade union which, by subscribing annually 110 guineas, was able to obtain traditional rights of recommendation. Ibid., pp. 26, 28.

${ }^{113}$ Ibid., p. 26. 


\section{Steven Cherry}

dispute that he is no friend to the hospitals but ... ignorant of the true principles of charity". ${ }^{114}$ Although the Saturday Fund conformed to the socially dominant themes of self-help and the curtailment of medical charity, it persisted with its own agenda. This occasioned public warnings that "the attempt now being made by certain ardent spirits to procure seats on the committees of management of the metropolitan charities through the Hospital Saturday organization should be discouraged on every ground of principle and morality". ${ }^{115}$ It also opposed the establishment of private pay-beds and called for the more humane treatment of hospital patients and their visitors. ${ }^{116}$ And it continued the basic argument that "the workingman ... thinks that a guinea contributed by himself and his shopmates is worth just as much as ... [one] contributed by the richest man ... and he is entitled to the same advantages". 117

In practice, roughly two-thirds of the Saturday Fund distribution went to hospitals, shared between general and special facilities, with additional convalescent and nursing grants. The remainder was for dispensaries or to assist individuals who requested medical aids or benefits. This implied a preparedness to accept available hospital resources on a quasi-charitable basis or in return for token contributions, a move towards more specialized hospital facilities and efforts to maximize limited fund resources and influence in the perceived interests of contributors. Thus, although the central distribution of funds was a goal held in common with the Sunday and King's funds, the Saturday movement had a very different social base and outlook, carrying principles of self-help to the point of assertions of entitlement.

\section{Issues in Hospital Fund-Raising}

Lacking sufficient financial leverage, the London Saturday Fund shared with the Sunday Fund an inability to exert real influence over metropolitan hospitals. Its minimal contribution to London voluntary hospitals has been established, but this represents an atypical base from which to generalize. From regional examples and the individual instances in the Appendices it is clear that elsewhere Saturday and works collections raised substantial funds. Some of the hospitals still benefited from endowments and windfalls but more had to consider grassroots sources for additional regular or ordinary income. National aggregate information has the effect of diluting the impact of the new sources, which were barely developed in some areas before 1900. Where the new schemes were well-organized they delivered substantial amounts: one-fifth to one-third of hospitals' ordinary income was not unusual in midland and northern industrial areas or in Scotland by 1890 . Greater proportions and emulation in parts of south Wales, the West Country and southern England followed by 1900. Hospitals in these latter areas sometimes received disguised contributions, more than

\footnotetext{
${ }^{114}$ Burdett's hospital annual, op. cit., note 43 above, p. cxvii.

${ }^{115}$ Ibid., p. cxvii.

${ }^{116}$ Hospital, 3 Nov. 1900, derided the National Federation of Women Workers' Conference whose "so-called debate" on hospitals addressed
}

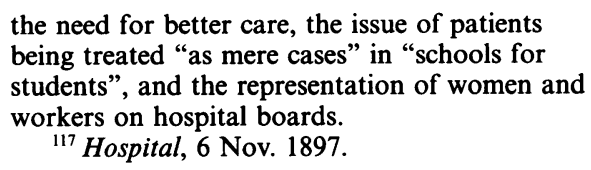

the need for better care, the issue of patients being treated "as mere cases" in "schools for students", and the representation of women and workers on hospital boards.

${ }^{117}$ Hospital, 6 Nov. 1897. 


\section{Hospital Saturday, Workplace Collections}

$£ 10,000$ "supported entirely by workmen's subscriptions ... to 16 hospitals and convalescent homes in towns on the Great Western Railway for the benefit of members" in 1900, for example. ${ }^{118}$ Thus, claims that "from 1873 the whole of any increased expenditure by the voluntary hospitals had been provided by the workers", ${ }_{119}$ or that "not until the workpeople's support was secure and growing was the Infirmary able to expand", ${ }^{120}$ are neither wholly inappropriate nor unrepresentative.

Until comparatively recently, historians allowed almost no gradation between voluntarism and self-help on the one hand and public or socialized medicine on the other. Before the emergence of municipal hospitals and eventually the NHS, fundraising for voluntary hospitals could be seen as primarily philanthropic and, as far as workers were concerned, an activity for the respectable or deferential. ${ }^{121}$ Where the local hospital evoked civic pride, or epitomized a sense of community, workers' involvement might reflect a unitary framework of ideas or subtle exercises in social control, engineered by their social betters. ${ }^{122}$ Change in the hospitals was sometimes recognized but the ascendancy of medical professionals over traditional philanthropists was seen as the critical feature. Even in towns where Saturday and workplace fund-raising was substantial, this represented "yet another way for workers to follow where their employers led". ${ }^{123}$

None of this can be discounted, yet such interpretations are incomplete. Although they barely feature in Geoffrey Finlayson's account, Saturday and works collections represent an example of the "citizenship of contribution", as an exercise in self-help, a contribution to the health care of others, and an expression of loyalty to a particular community. ${ }^{124}$ Such effort was pro-active, to secure appropriate medical attention, rather than merely in response to externally-initiated campaigns to curb "abuse" of medical charities or to the hospitals' appeals for funds. Workers' involvement in the establishment of a number of hospitals-and not only cottage hospitals-in Lancashire, south Yorkshire and the north-east featured contributions to capital costs rather than passive utilization of facilities. ${ }^{125}$ It could also reflect the concerns of a specific section of the community and differing motives, rather than a unitary outlook shared with or copied from social betters. This sometimes extended to direct criticism: when a governor of Greenock Infirmary suggested in 1875 that workers could do more to help, the Secretary of the Joiners Association responded; "if $\mathrm{Mr}$ S. started and lived on 20 shillings a week he would find it hard enough ... his trade

\footnotetext{
${ }^{118}$ Burdett's hospitals and charities, 1900, p. 477.

${ }^{119}$ E R Sherlock, 1873-1973, the golden years: a concise history of the Birmingham Hospital Saturday Fund, Birmingham Hospital Saturday Fund, 1973, p. 24.

${ }^{120}$ Pickstone, op. cit., note 12 above, p. 144.

${ }^{121}$ Brian Abel Smith, The hospitals, 1800-1948, London, Heinemann, 1964, p. 386; Paul Johnson, Saving and spending, Oxford, Clarendon Press, 1985, p. 232.

${ }_{122}$ Yeo, op. cit., note 8 above, notes among dissenting groups the Social Democratic Federation.
}

\footnotetext{
${ }^{123}$ Pickstone, op. cit., note 12 above, p. 140 . 408 .

${ }^{124}$ Finlayson, op. cit., note 7 above, pp. 68 ,

${ }^{125}$ Provision of children's wards in such hospitals was often a priority, with capital costs mainly or wholly provided by collections in Preston (1884), Grimsby (1894) and Barnsley (1898), for example. Wilkinson, op. cit., note 64 above, (Preston), Barnsley Beckett Hospital, Annual report, 1898.
} 


\section{Steven Cherry}

had subscribed more this year than last ... he did not see why only $£ 758$ should be subscribed by gentlemen among whom were sugar refiners and shipbuilders ... they should just put their hands a little deeper into their pockets". ${ }^{126}$

Such criticism was not likely to be publicized by hospital authorities, but it compounds the issues of interpretation and meaning attached to philanthropic effort. What voluntarist advocates saw as support and endorsement for charitable institutions, worker-contributors might see as an essay into the "citizenship of entitlement", enhancing their access to hospital care. This latter claim was problematic for hospital authorities and administrators. They were grateful for new income, but often resisted any obligation to treat those who contributed or to allow rights of recommendation to contributing bodies. They were indeed exhorted to resist by some advocates of the charitable approach but the variable response of hospital administrators suggested pragmatism and an eye for longer term changes. Before 1870 the Sheffield hospitals had refused to extend patient-recommendation to collecting bodies as a matter of philanthropic principle: twenty years later, Liverpool hospitals argued in the language of medical autonomy and clinical control. ${ }^{127}$ When an officer of the Exeter Saturday Fund suggested in 1890 that "working men were entitled to the benefits of institutions which they supported", the Hospital replied in magisterial fashion, "It is plain that workingmen are very much at sea with regard to hospitals and their management, and also ... their own rights and privileges therein. The truth is that they have no 'rights' at all, but only 'privileges'". ${ }^{128}$ Yet this argument was destroyed by the Hospital's own berating of those workers who gave small amounts, its praise of those who gave more, and its view that "they can acquire rights by paying for them". ${ }^{129}$

In fact there were early-nineteenth-century instances where workers jointly had paid a "traditional" annual subscription, as in Leicester and Dundee. Many other hospitals had long conceded that Saturday funds or workplace collecting bodies could recommend patients, even if the individual concerned had no contractual arrangement. In English provincial hospitals the extension of recommendations often occurred via collective friendly society or works "subscriptions" to workplace and Saturday collections by the early 1870 s, particularly where the latter formed the largest category of income, and the traditional emphasis upon subscriberrecommendation was already in decline. ${ }^{130}$ The Edinburgh Royal Infirmary combined a traditional emphasis upon treating the sick poor with a rough acceptance that,

\footnotetext{
${ }^{126}$ Greenock Infirmary Annual Report, 1875, in Ferrier, op. cit., note 60 above, pp. 91-2.

${ }^{127}$ Press correspondence in Liverpool centred upon the medical staff's right to refuse admission and the Saturday Fund contributors' expectation of treatment. C Brewer, A brief history of Liverpool Royal Infirmary 1887-1978, Liverpool, Area Health Authority, 1980, p. 27. For Sheffield, see note 77 above.

${ }^{128}$ Hospital, 18 Jan. 1890, p. 240.

${ }^{129}$ Ibid., p. 240.

${ }^{130}$ Northampton General Hospital unusually refused this concession until 1904, the first of
}

\begin{abstract}
disagreements between hospital authorities and the Saturday movement. F F Waddy, $A$ history of Northampton General Hospital 1743 to 1948, Northampton, Guildhall Press for Northampton and District Hospital Management Committee, 1974 , pp. 124-6. The average percentage of patients not traditionally recommended from 1850-1880 was at Leicester 21 per cent, Worcester, 23 per cent, Norfolk and Norwich 26 per cent, Manchester 38 per cent, Leeds 40 per cent. Cherry, op. cit. note 38 above, p. 124.
\end{abstract}




\section{Hospital Saturday, Workplace Collections}

overall, workplace collections covered their recommendations. At Glasgow Royal Infirmary there was a high proportion of accident cases which by-passed the subscriber recommendation system. But not all were happy with a discriminatory arrangement, whereby the workplace providing a collection of $£ 10$ was allowed the equivalent "lines" of recommendation as an annual subscriber of one guinea. ${ }^{131}$ There were also complaints "that the medical men ... gave preference to the tickets of the larger subscribers", as in Greenock in 1883. ${ }^{132}$ And although Burdett assumed that with substantial works collections "the working men ... had as many tickets as they wanted", the Western Infirmary had completely abolished such tickets by then. ${ }^{133}$

The above suggests a pragmatic resolution of one source of tension, between contribution and entitlement, in an apparently cohesive voluntarist framework. A second lay in contributors' demands for representation in hospital government. There was one Saturday Fund representative on the Board of Management at Nottingham General Hospital from 1872 and four at the Coventry and Warwickshire in 1875, with Birmingham, Chester, Preston and Blackburn among other early examples by $1883 .{ }^{134}$ This may have been tokenistic on Merseyside, where one representative from the joint Saturday and Sunday Fund was appointed to each hospital in the area in 1895. It was less so on Tyneside, where representatives elected from supporting workplaces held 9 of the seats on the 32 member Management Committee from 1887, and a more active role could be expected in smaller hospitals founded by and dominated by friendly societies or trade union welfare associations. ${ }^{135}$ Similarly, provision made at executive levels for three workmen's governors elected from supporting workplaces, at Glasgow Victoria Infirmary in 1888 and at the Cardiff Royal and Newcastle Royal infirmaries by 1900, indicates signs of change in some hospitals. ${ }^{136}$

This is not to say that workers obtained pro rata representation or that this now became a requirement in fund-raising. But there were early indicators that support should signal an end to patronizing attitudes or the payment of hospital registration fees, as in Birmingham. ${ }^{137}$ With varying degrees of success, a voice within the system and equitable status with traditional subscribers were generally pursued, the London

${ }^{131}$ Olive Checkland, Philanthropy in Victorian Scotland, Edinburgh, John Donald, 1980, p. 162.

${ }^{132}$ Ibid., p. 92.

${ }^{133}$ Burdett, op. cit., note 71 above, p. 31; Ferrier, op. cit., note 60 above, p. 92.

${ }^{134} \mathrm{~F}$ H Jacob, $A$ history of the General Hospital near Nottingham, Bristol, John Wright, 1951, p. 311; Tugwood, op. cit., note 72 above, p. 40. The Coventry and Warwickshire Hospital could recommend up to 264 patients that year. At Preston Royal Infirmary, the number of representatives was increased to four in 1899. Wilkinson, op. cit., note 64 above, p. 47.

${ }^{135}$ Burdett's hospital annual, op. cit., note 43 above, p. 157. The latter included Mexborough and Gorleston hospitals, both founded in 1889 . Rotherham hospital had 21 "worker representatives" on its governing body in 1885 .

\footnotetext{
${ }^{136} \mathrm{~S}$ Slater and D Dow, The Victoria Infirmary of Glasgow 1890-1990, Glasgow, Victoria Infirmary Centenary Committee, 1990, p. 55; Hospital, 24 March 1900, p. 420. Nottingham General Hospital was among the first of the major hospitals to have a worker representative elected to its Weekly Board in 1890. Hospital, 26 April 1890, p. 50.

${ }^{137} \mathrm{Mr}$ Dawson, Saltley Works delegate to the Birmingham Workmen's Fund meeting in January 1869 , argued "there was no reason why the working classes should not turn charitable into co-operative institutions", meanwhile, "why should the old man not have ... a note of recommendation signed by duly elected representatives of Saltley Works?" Gamgee, op. cit., note 68 above, pp. 7, 9.
} 


\section{Steven Cherry}

Saturday Fund illustrating that financial clout was likely to be more persuasive than the assertion of rights. Where funding was not tied to or organized from a particular hospital, distinct efforts could be made to establish additional facilities, directly or via grants, the principal hospitals' immediate concern being that they should not receive reduced funding in consequence of such diversification. ${ }^{138}$ Children's wards, dispensary and convalescent provision, nursing and rudimentary ambulance services usually featured, as in Birmingham, Bradford, Leeds and Sheffield. Again this suggests some modification of support for any one institution or the acceptance of employer agendas focused upon accident hospitals or male breadwinners.

What did such developments portend? If grants to free dispensaries represented a continuation of medical charity and a cheap rival to hospitals, support for provident institutions was a dangerous encroachment with echoes of club practice. What if "the whole affair becomes a mere business, whose very object would seem to be provision of contract medical attendance at the lowest possible price". ${ }^{139}$ Convalescent treatment might represent a diversion of resources, "collected in the name of the hospital and ... kept completely in control of the officers of the convalescent fund". ${ }^{140}$ The very success of workers' fund-raising could pose a threat, engendering a reverse dependency. Thus, "the Birmingham medical institutions are tied to the Saturday fund ... they are forced to watch the slow absorption of their charities by a great co-operative movement. This is what a workingman's organisation does at its best. What it will do at its worst we do not know". ${ }^{141}$

If the latter included the exertion of influence upon hospital policy-making or alternative forms of organization, there was little evidence of a direct or politicized challenge before $1900 .^{142}$ A detailed socialistic alternative had not been formulated, there were few supporters for the municipalization of voluntary hospitals and the Co-operators who felt that "by co-operation they had displaced a lot of people who would have otherwise been subscribers" had misread the nature of the wider collecting effort. ${ }^{143}$ But different priorities within the voluntary system were asserted. Examples included the campaign by the Leeds Workpeople's Hospital Fund for a new southern infirmary because of overcrowding at the Leeds General, and the part withholding of collections in Barnsley because the hospital sought to restrict patients recommended by the Saturday Fund. ${ }^{144}$ Less directly, the provision of "other" facilities in Birmingham or the London Saturday Fund's attention to special hospitals and "miscellaneous" institutions, suggest objectives additional to fund-raising. Almost

\footnotetext{
${ }^{138}$ Nursing grants often featured in towns (e.g. Bolton) where the general infirmary solely provided non-Poor Law hospital beds.

${ }^{139}$ Hospital, 21 Oct. 1899.

${ }^{140}$ This was alleged by Northampton General Hospital authorities. Waddy, op. cit., note 130 above, p. 124.

${ }^{141}$ Hospital, 25 Sept. 1897. Gratitude and fear were similarly expressed over central government grants in the Great War and local authority contract work afterwards.

142 "Political" alternatives beyond the claims of alternative medicines, or better health and
}

lifestyles under socialism were underdeveloped, although the Fabian Society and Independent Labour Party favoured the reorganization of public or municipal services. 1897.

${ }^{143} \mathrm{~F}$ Midgely, cited in Hospital, 8 May

${ }^{144}$ Barnsley Beckett Hospital, Annual report, 1900 . With an increase in workingmen governors "and a corresponding change in some of the ideas expressed ... unless the standpoint of those responsible for the management of the hospital is clearly defined, there is some risk of misunderstanding". 


\section{Hospital Saturday, Workplace Collections}

everywhere, Hospital Saturday or works collections increased over the late nineteenth century. Outside London, even where several hospitals competed for funds and though workers' contributions were particularly sensitive to the state of the economy, as in Glasgow, "there is no evidence of any general fall-off in interest among workmen over this period ... rather the reverse". ${ }^{145}$

Some in the voluntary hospital movement had spotted a Trojan horse emerging from the different social class and cultural dimensions to the new fund-raising to threaten their own dominance. Recognizing the inequity of previous variations in subscriber/recommendation arrangements, the Hospital by 1900 noted "the cooperative principle which places 'shop collections' on a totally different plane from ordinary subscriptions, and is the reason and excuse for the special arrangements made in so many hospitals for the representation of the workingmen subscribers on the boards of management". ${ }^{146}$ Even if these special arrangements were tokenistic, what would be the implications of further increases in such funding, or the passage of time? "If working class 'representative' governors were to become a numerous and powerful body it would be difficult to prevent 'charity' being ousted by 'cooperation" ". ${ }^{147}$ Ultimately there lurked the possibility "of hospitals being captured by the organised trade subscribers and used for class purposes... . In some places this is a very real danger". ${ }^{148}$

This was an alarmist, top-downwards, and class-polarized summary of trends in the voluntary hospital movement by $1900 .{ }^{149}$ It had a mirror image, though neither reflected the largely collaborative fund-raising of the preceding four decades. But such effort was not insignificant or deferential. Hospital Saturday and particularly workplace collections have been undervalued: in regard to the philanthropy of the wealthy, in comparison with Hospital Sunday, and in association with the relative trivialities of flag day and collecting box imagery. In fact, they contributed very substantially to hospital funding in many areas, they greatly facilitated the continued expansion of voluntary hospitals, and they helped to safeguard popular access to hospital facilities. They also indicate positive and sometimes independent interest in health care which was sustained over the twentieth century, though increasingly then expressed in collectivist and political terms. ${ }^{150}$

${ }^{145}$ Caffney, op. cit., note 40 above, p. 86

${ }^{146}$ Hospital, 24 March 1900, p. 420.

${ }^{147}$ Ibid.

${ }^{148}$ Ibid.

${ }^{149}$ Twentieth-century hospital contributory schemes, even more important to voluntary hospitals, noticeably took care to encourage worker participation, particularly in Sheffield and on Merseyside. The works collection or Saturday format remained intact in many Midland, northern and Scottish towns until the Second World War. Elsewhere, contributory schemes (e.g. the Sussex Scheme) developed on geographic, family and unitary lines for those unable to afford private fees. In London, the Hospital Savings Association, an offshoot from the King's Fund, largely replaced Hospital Saturday as the "popular" form of contribution. J E Stone, Hospital organisation and management, 3rd ed., London, 1939.

${ }^{150}$ Earwicker, op. cit., note 26 above; Charles Webster, 'Labour and the N.H.S.', in N A Rupke (ed.), Science, politics and the public good, Basingstoke, Macmillan, 1988, pp. 184-202. 
Steven Cherry

APPENDIX 1

Contributions from Saturday and workplace collections to ordinary income in specific hospitals, by region

Percentage of hospital ordinary income provided Early collection or early example $\quad 1890 \quad 1900$

MIDLANDS

Birmingham General

1873

Birmingham Queen's

Burton on Trent

Coventry \& Warwick

Derbyshire R. Inf.

Leicester R. Inf.

Northampton Gen.

Nottingham Gen.

Staffs, R., Stoke

Walsall

West Bromwich

Wolverhampton

\section{NORTH WEST}

4 Liverpool hospitals

Manchester R. Inf.

Blackburn \& E. Lancs

Bolton R. Inf.

Bootle

Burnley

Bury

Chester General

Preston R. Inf.

Salford R. Hosp.

Stockport

Wigan

\section{YORKS/HUMBERSIDE}

2 Sheffield hospitals

Leeds Gen. Inf.

Barnsley Beckett

Bradford R. Inf.

Chesterfield R. Inf.

Doncaster Inf.

Halifax Inf.

Huddersfield Inf.

Hull R. Inf.

Lincoln C. Hosp.

Rotherham Hosp.

Clayton, Wakefield

York County Hosp.

1871

1868

1870

1871

1873

1868
$17.1 \quad 12.9$

$22.9 \quad 20.9$

$36.9 \quad 33.4$

$31.9 \quad 37.1$

$18.4 \quad 14.9$

$25.0 \quad 31.5$

$15.1 \quad 10.7$

$20.0 \quad 27.5$

$24.7 \quad 57.3$

$45.6 \quad 54.0$

1872 (1872-82: $£ 745$ p.a.) $\quad 62.1$

1869 (1872-82: $£ 1,430$ p.a.) $\quad 42.7 \quad 44.2$

$1872(1873: £ 1,499)$

$1877(1877: £ 1,300)$

$13.1 \quad 23.8$

$\begin{array}{ll}5.0 & 3.8\end{array}$

$37.8 \quad 32.5$

$40.2 \quad 46.4$

$28.0 \quad 25.6$

33.7

40.2

1882: $21 \%$

6.6

$34.6 \quad 33.5$

$9.8 \quad 4.3$

$19.1 \quad 22.2$

62.5

$19.5 \quad 22.4$

$22.3 \quad 22.7$

1883-5: $32 \%$

$39.7 \quad 38.0$

$22.4 \quad 37.5$

33.9

1875 (1880: £300) $\quad 16.1 \quad 17.6$

$30.5 \quad 35.3$

$15.7 \quad 17.1$

$27.5 \quad 27.3$

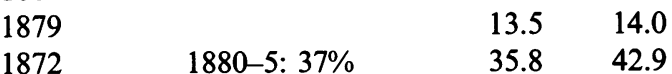

1876 (1876-83: £757 p.a.) $\quad 35.8 \quad 19.4$

$\begin{array}{ll}7.6 & 7.7\end{array}$ 


\section{APPENDIX 1}

continued

Percentage of hospital ordinary income provided

Early collection or early example $\quad 1890 \quad 1900$

\section{NORTH EAST}

Newcastle R. Inf.

Hartlepool

Middbro, N. Ormesby

Stockton

Sunderland R. Inf.

SOUTH and EAST

"All London"

Addenbrooke's, Cambs

Colchester, N. Essex

Ipswich, E. Suffolk

Norfolk \& Norwich

Brighton R. Sussex

Folkestone, R. Victoria

Kent and Canterbury

Portsmouth

Reading, R. Berks

Winchester C. Hosp.

\section{S. WEST/WALES}

2 Bristol hospitals

Devon \& Exeter

Gloucester

Stroud

Cardiff R. Inf.

Swansea R. Inf.

$\begin{array}{llll} & & 28.3 & 42.2 \\ & & 34.5 & 38.2 \\ 1859 & 1860: 22 \% 1882: 44 \% & 40.2 & \\ & & 56.2 & 74.0 \\ 1861 & 1871: 17 \% 1878: 35 \% & 49.9 & 64.1\end{array}$

1873 (1874-81: £6,334 p.a.)

$\begin{array}{ll}1.8 & 2.0\end{array}$

$2.9 \quad 3.1$

$14.6 \quad 16.3$

$1883 \quad 1883: 16 \% \quad r .6 \quad 16.3$

1873

$4.3 \quad 6.7$

$\begin{array}{lrr}1890 & 10.5 & 7.1\end{array}$

$14.2 \quad 11.6$

$5.2 \quad 10.9$

$7.6 \quad 15.2$

$5.2 \quad 5.3$

$2.3 \quad 2.7$

1875

1876-8: $2 \%$

$17.4 \quad 17.1$

$8.2 \quad 4.8$

$7.9 \quad 5.6$

$24.3 \quad 24.0$

$17.6 \quad 24.0$

$15.4 \quad 29.3$

Sources: Early examples from secondary texts (see footnotes), and G Palliser, et al., The charitable work of hospital contributory schemes, Bristol, British Hospitals Contributory Schemes Association, 1984, 1890; Henry Burdett, Hospitals and asylums of the world, London, J and A Churchill, 1893, vol. 3, pp. 213-14; and Burdett's hospital annual, London, Scientific Press, 1891, pp. lxv-lxviii, and individual entries in Directory section; Burdett's hospitals and charities, 1900, pp. 115-18, and Directory section. 


\section{Steven Cherry}

APPENDIX 2

Workplace collections and their contribution to ordinary income in specific Scottish Hospitals

\begin{tabular}{|c|c|c|c|c|c|c|}
\hline & \multirow{2}{*}{$\begin{array}{l}\text { Known early } \\
\text { collections }\end{array}$} & \multicolumn{5}{|c|}{ Percentage of ordinary income } \\
\hline & & early date & 1870 s & $1880 \mathrm{~s}$ & 1890 s & 1900 \\
\hline Glasgow Royal Inf. & 1841 & $7.6(1841)$ & 32.6 & 28.9 & 29.5 & 29.9 \\
\hline Glasgow Western Inf. & 1877 & $17.0(1877)$ & & 23.3 & 26.2 & 29.4 \\
\hline Glasgow Victoria Inf. & & & & & 23.8 & 24.8 \\
\hline Edinburgh Royal Inf. & 1849 & & & & $14.4^{*}$ & 17.6 \\
\hline Dundee Royal Inf. & 1822 & $11.0(1822)$ & & & $25.8^{*}$ & 23.3 \\
\hline Aberdeen Royal Inf. & 1883 & $8.0(1883)$ & & & 9.7 & 12.7 \\
\hline Arbroath Inf. & & & & & $9.2^{*}$ & \\
\hline Ayr County Hospital & & & & & $7.1^{*}$ & 4.8 \\
\hline Dumfriesshire R. Inf. & & & & & $2.2^{*}$ & 6.2 \\
\hline Greenock Inf. & 1832 & & & & $18.9^{*}$ & 20.0 \\
\hline Kilmarnock Inf. & & & & & $28.1^{*}$ & 29.7 \\
\hline Leith Hospital & 1869 & & & & & \\
\hline Paisley, R. Alexandra & & & & & $13.3^{*}$ & 13.8 \\
\hline
\end{tabular}

Note ${ }^{*} 1895-1900$ only in Scottish examples

Sources: early examples from secondary texts (see footnotes); ' 1890 ', Burdett's hospital annual, London, Scientific Press, 1891, pp. lxv-lxviii, and individual entries in Directory section; H C Burdett, Hospitals and asylums of the world, London, J and A Churchill, 1893, vol. 3, pp. 213-14; Burdett's hospitals and charities, 1900, pp. 115-18, and Directory section. 